\title{
Analysis of Student's Biology Science Process Skills in High Schools of Kisaran City
}

\author{
Leny Herawati ${ }^{1}$, Melva Silitonga ${ }^{2 *}$, Ahmad Rafiqi Tantawi ${ }^{2}$ \\ ${ }^{I}$ Student of Postgraduate Biologi Education, State University of Medan, Medan, Indonesia \\ ${ }^{2}$ Lecturer of Postgraduate Biology Education, State University of Medan, Medan, Indonesia
}

*Corresponding Author: Melva Silitonga, Lecturer of Postgraduate Biology Education, State University of Medan, Medan, Indonesia

\begin{abstract}
This research was conducted to describe science process skills of ten grader high school students in Kisaran City, and to find out their score in each aspect of science process skills. This research was descriptive quantitative which describe and explain data based on real situation occurred on field. Research population was all ten grader high school students in Kisaran City, which was taken by purposive sampling. Student's science process skills were measured by using 9 questions of essay test about environmental pollution. The result showed that the average score of student's science process skills were 78,49 (good category). The lowest aspect was found at aspect of hypothesis with average score 56.46 (poor category)
\end{abstract}

Keywords: science process skills, Kisaran City

\section{INTRODUCTION}

Education is an important factor in building the Nation. Therefore, the quality of education should be improved in accordance with development of science and education. Education is one of the basic instruments used to transmit the value of society to the younger generation (Akani, 2015). Education has an important role in facing global challenges which continuously become more difficult and change in all aspects. Therefore, to face these challenges, science process skills are needed (Subiantoro, 2011).

Natural science is a collection of systematically arranged knowledge, which its use in general is limited to natural symptoms. From the importance of learning science that develops the scientific process to the formation of student mindset (Rutten, et al., 2012). In learning science, it is important to develop scientific processes to form student's mindsets (Rutten et al., 2012). One branch of science is Biology. Biology itself is based on experiments with scientific processes or known as science processes. The process includes observation (observation), grouping (classification), interpreting, predicting, concluding and communicating (Afaloby, 2010).

This science process becomes a skill that students must possess in studying biology. Then this skill is known as science process skills. It is important for teachers to train science process skills to students. This is because it can equip students with a thinking skill and act through science to solve problems and explain phenomena that exist in everyday life. Therefore student's science process skills need to be improved (Ergin, 2008).

Science process skills divided into two levels, which are basic science process skill and integrated science process skill. Science process skills include skill to observe, classify, communicate, measure, predict and conclude (Karamustafaoglu, 2011).

According to Chebii (2012), effective science learning depends on the method used by the teacher during the learning process. In science learning, the best method is when students actively participate in class. The activities could be conducting experiments, conducting demonstrations, class discussions and other relevant learning experiences.

Science process skills are very important to be mastered and applied by students in relation to how students are able to observe, classify, interpret, predict, ask questions, hypothesize, plan experiments, 
apply concepts, and communicate. Therefore, all educators (teachers) should teach students to use science process skills. Teaching with science process skills means providing opportunities for students to work with science.

Some studies explain that in the field of Biology, students still experience low science process skills. According to Roviati (2016), in studying the Ecosystem topic, student's science process skills in experiment class looking from each aspect was low, such as aspect of planning experiments has 0.28 $\mathrm{N}$-gain score, as aspect of observation has $0.19 \mathrm{~N}$-gain score, which are very low. Low scores also seen in aspect of predict and conclude, which has $N$-gain 0,20 and $N$-gain 0,16 . In line with Pujinigrum (2017), the results of his research show that the low level of science process skills causes students to be poorly trained to discover facts themselves.

Based on explanations above, it turns out that student's low level of science process skills in biology topics comes from student's internal and external factors. Factors that lead to low science process skills in students may occur because: 1 . the teachers themselves do not understand science process skills; 2 . teachers only explains science in form of product and only a little bit of process; 3 . tendency of using multiple choice questions or essay tests on daily basis or summative test; 4 . Low quality of question, or the problem does not raise questions that contain science process skills.

Research on science process skills is very important to do, to make teachers know more about science process skills in order to develop biology teaching and learning activities so that later the learning outcomes can be better. Rostika (2012) stated that learning activities should prepare students who have the ability to solve problems, be critical, and be creative, weather it is national, regional, and global problem. From the description above, it is necessary to do a study of the analysis of student's science process skills in Kisaran City High Schools.

\section{MATERial AND Method}

\subsection{Research Design}

This research was descriptive quantitative research or survey method. This research was held at National high school in Kisaran City from October to November 2017. The population was all ten grader science students at National high school in Kisaran City.

\subsection{Study Samples}

The population was all ten grader science students at National high school in Kisaran City (864 students). The samples were taken by purposive sampling. The samples taken were four schools with Adiwiyata certified or program aims to create a caring school environment (SMA Negeri 1 Kisaran, SMA Negeri 2 Kisaran, SMA Negeri 3 Kisaran and SMA Negeri 4 Kisaran). One class was picked out as sample from each school. The class picked out was the one which passed the exam of environmental pollution topic. Total sample in this research was 144 students.

\subsection{Instrument}

The data of student's science process skills was collected by using an essay test, which embraced all science process skills indicators, such as ability to observe, classify, interpret, predict, ask questions, hypothesize, plan experiments, apply concepts, and communicate. The test was arranged according to biology curriculum used in tenth grade. Student's science process skills was score by using formula:

$\mathrm{S}=\frac{\mathrm{R}}{\mathrm{N}} \mathrm{X} 100$ (Purwanto, 2013)

Note:

$\mathrm{S}=$ science process skills score

$\mathrm{R}=$ score obtained from correct answers

$\mathrm{N}=$ maximum score

The result of data calculation of student's science process skills then categorized according to criteria (table 1) as follows: 
Inclusive Education: Education and Development of Persons with Disabilities in the Buea Municipality, Fako Division, South West Region of Cameroon

Table1: Student's science process skills criteria

\begin{tabular}{|l|l|l|}
\hline \multicolumn{1}{|c|}{ No } & \multicolumn{1}{|c|}{ Score Interval } & \multicolumn{1}{c|}{ Criteria } \\
\hline 1 & $86-100$ & \multicolumn{1}{|c|}{ Very good } \\
\hline 2 & $76-85$ & Good \\
\hline 3 & $66-75$ & Average \\
\hline 4 & $56-65$ & Poor \\
\hline 5 & $<55$ & Unsatisfactory \\
\hline
\end{tabular}

\section{RESULT \& DISCUSSION}

\subsection{Result}

Student's science process skills in general

Data of student's science process skills was obtained after student's answer all questions in test. The first analysis was counting how many correct answer student obtained and classified them according to criteria. Student's science process skills in four schools in Kisaran City displayed in table 2 below:

Table2: Student's science process skills in four schools in Kisaran City

\begin{tabular}{|l|l|l|l|}
\hline \multicolumn{1}{|c|}{ School name } & Total student & Average score of student's science process skills & Categories \\
\hline SMA N1 Kisaran & 36 students & 77.01 & Good \\
\hline SMA N2 Kisaran & 36 students & 81.35 & Good \\
\hline SMA N3 Kisaran & 36 students & 76.79 & Good \\
\hline SMA N4 Kisaran & 36 students & 78.82 & Good \\
\hline Total & 144 students & 78.49 & Good \\
\hline
\end{tabular}

According to table 2 above the average score of tenth grade student's science process skills in Kisaran City was good. Sequentially, school that obtained the highest score of science process skills was SMA Negeri 2, followed by SMA Negeri 4, SMA Negeri 1, and the last SMA Negeri 3. The result of student's science process skills in Kisaran City as a whole can be seen in figure 1 below.

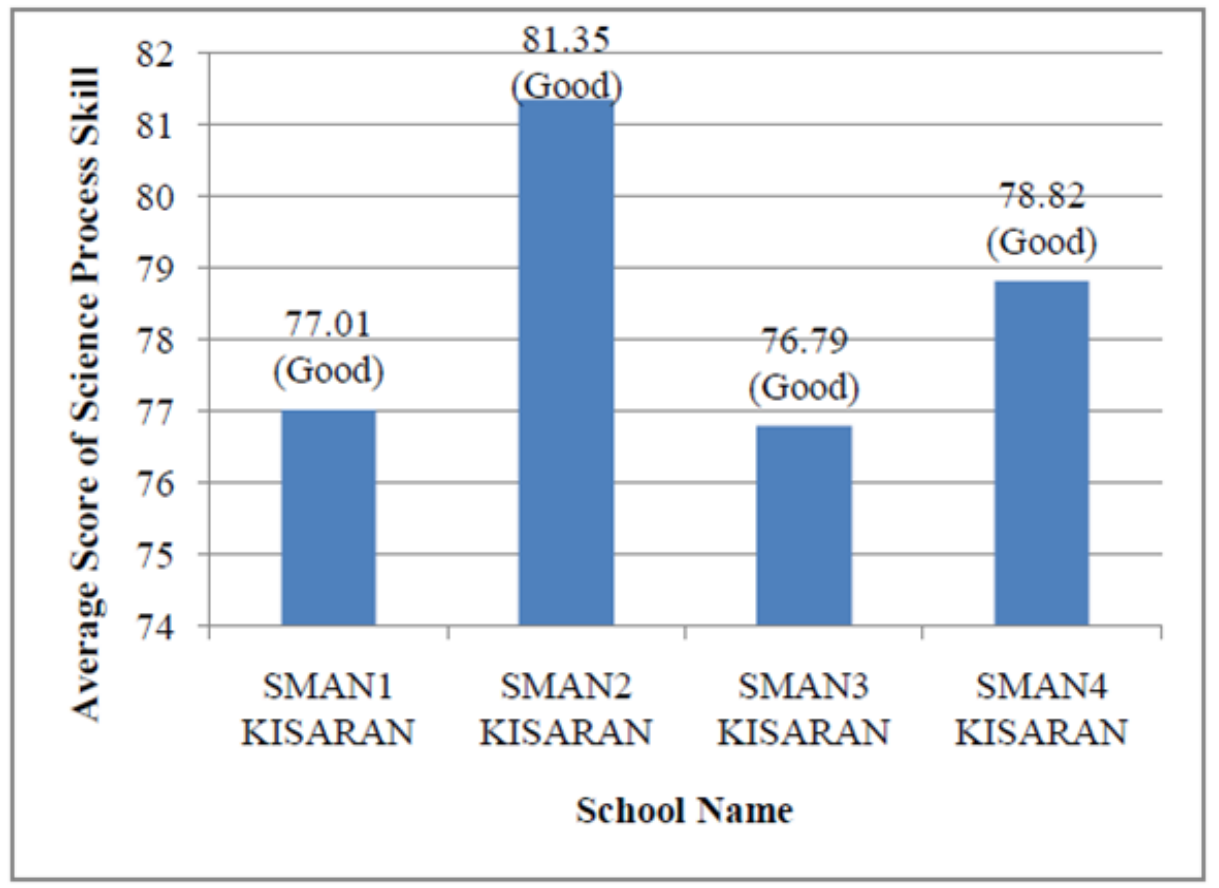

Figure1: Bar chart of student's science process skills in Kisaran City

In general, the result showed that most of students already have the characteristics of an individual who is literate to science, so students are able to associate the concepts obtained into everyday life. With these achievements students not only achieve ability to memorize, recognize facts, principles but also able to associate and apply these concepts into everyday life. Therefore, learning based scientific literacy and scientific approach can build student's positive attitude towards science. Further, these skills also affect the personal, social, and global lives of individuals. This increases the value of the 
Inclusive Education: Education and Development of Persons with Disabilities in the Buea Municipality, Fako Division, South West Region of Cameroon

science of learning as students gain a broad understanding and practical conception of the concepts of how scientific and principles apply in their personal, family, society and nation. In fact, the acquisition of science process skills offers excitement and enthusiasm for learning and motivates students to appreciate and pursue lifelong learning that leads to global excellence in education.

Student's science process skills in each aspect

Advanced analysis was done to find out the score of student's science process skills in each aspect. Nine aspects were observed, which were: the skills of observing, classifying, interpreting, predicting, asking questions, hypothesizing, planning experiments, applying concepts, and communicating. The whole results in every school observed displayed in table 3 and figure 2 below:

Table3: Student's scores in each aspect of science process skills in Kisaran City

\begin{tabular}{|l|l|l|l|l|l|l|}
\hline \multirow{2}{*}{ No } & \multirow{2}{*}{$\begin{array}{c}\text { Science Process Skills } \\
\text { Aspects }\end{array}$} & \multicolumn{4}{|c|}{ Science Process Skills Scores } & Average score \\
\cline { 3 - 7 } & & \multicolumn{1}{|c|}{ SMAN1 } & SMAN2 & SMAN3 & SMAN4 & \\
\hline 1 & Observing & 88.32 & 96.62 & 87.23 & 90.62 & 90.70 \\
\hline 2 & Classifying & 87.21 & 95.37 & 89.23 & 88.87 & 90.17 \\
\hline 3 & Interpreting & 61.66 & 66.87 & 59.76 & 63.37 & 62.92 \\
\hline 4 & Predicting & 66.10 & 67.50 & 65.38 & 67.00 & 66.80 \\
\hline 5 & Asking questions & 92.77 & 96.50 & 94.53 & 97.50 & 95.32 \\
\hline 6 & Hypothesizing & 59.44 & 63.62 & 54.46 & 56.75 & 58.56 \\
\hline 7 & Planning experiments & 85.55 & 87.87 & 85.23 & 89.00 & 86.91 \\
\hline 8 & Applying concepts & 62.22 & 64.75 & 61.53 & 61.02 & 62.38 \\
\hline 9 & Communicating & 88.88 & 92.37 & 88.84 & 92.75 & 90.71 \\
\hline \multicolumn{2}{|l|}{ Total score } & 76.90 & 81.27 & 76.21 & 78.54 & 78.23 \\
\hline
\end{tabular}

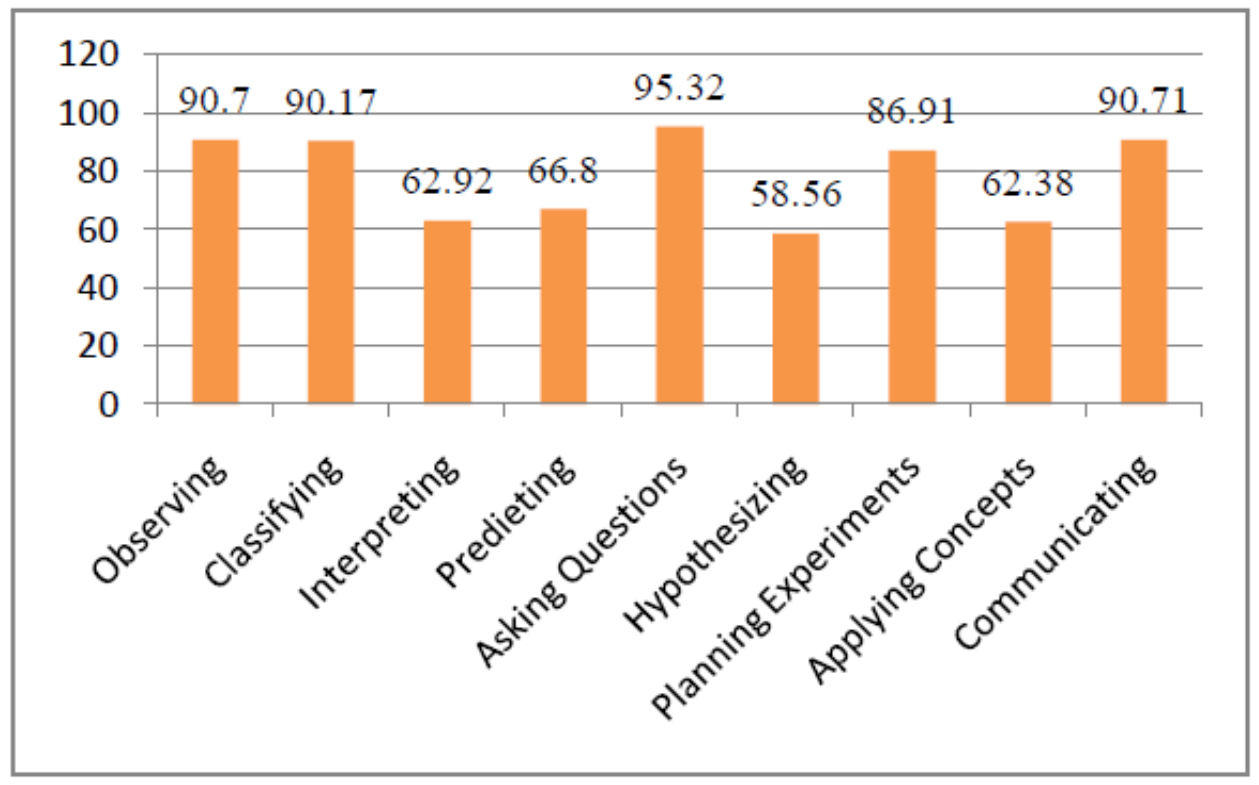

Figure2: Bar chart of student's scores in each aspect of science process skills in Kisaran City

Sequentially, student's science process skills score form the highest to the lowest were skills of asking questions, communicating, observing, classifying, planning experiments, predicting, interpreting, applying concepts, and hypothesizing. Aspect of asking questions was aspect obtained if students proposed questions (what, why, how, when, where) which aims to ask for an explanation or question that has a hypothetical background. The result showed that in this aspect, students in Kisaran City was considering have a very good skill in asking questions (95.32). However, student's skill of hypothesizing in Kisaran City was poor (58.56).

\subsubsection{Student's Science Process Skills in SMA Negeri 1 Kisaran City}

Student's science process skills in SMA Negeri 1 Kisaran City as a whole was grouped in good category (table 1 and table 3). Looking from its each aspect of science process skills (figure 3), it was found out that the highest aspect obtained was aspect of observing (88.31) and the lowest aspect was hypothesizing (59.44). 
Inclusive Education: Education and Development of Persons with Disabilities in the Buea Municipality, Fako Division, South West Region of Cameroon

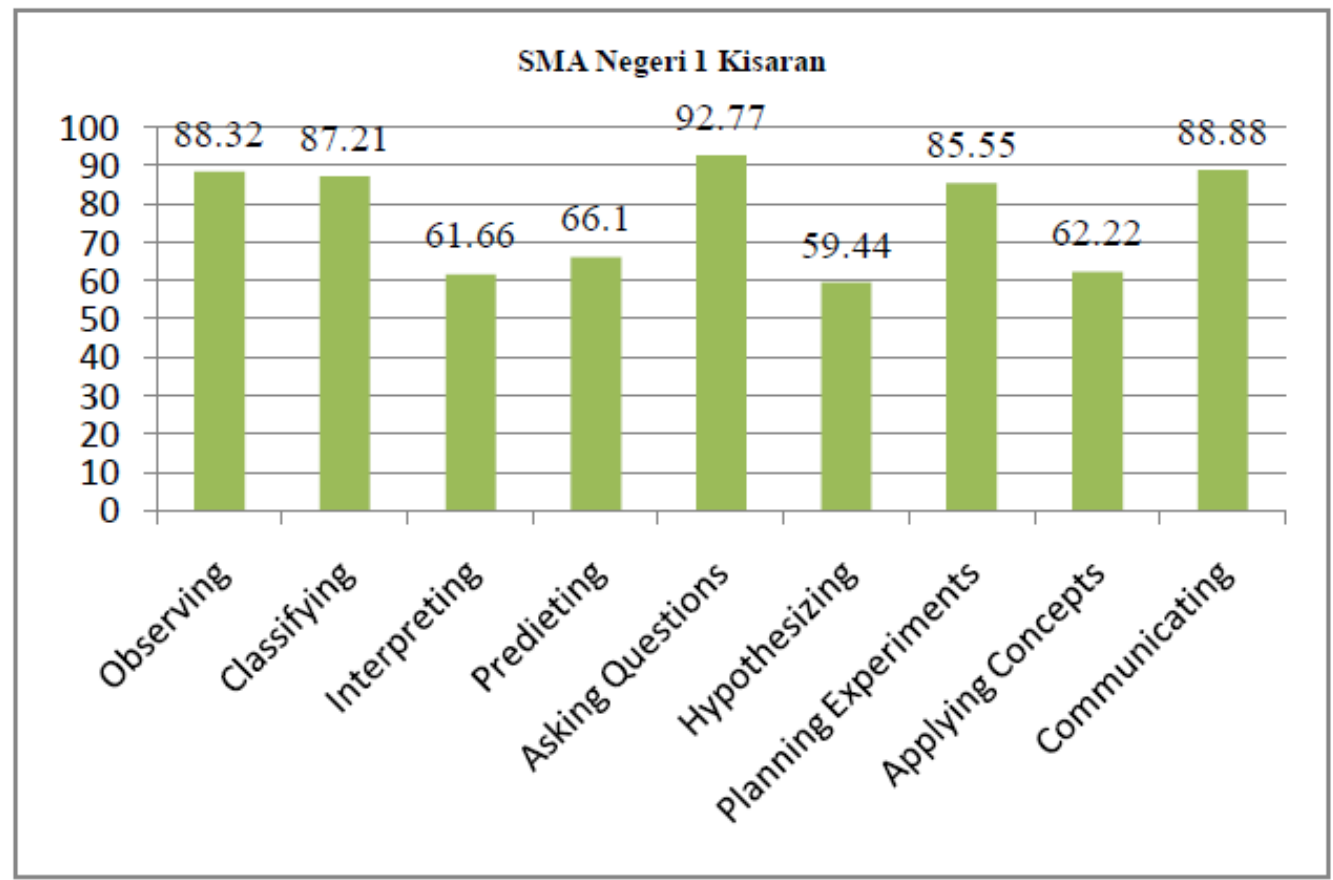

Figure3: Bar chart of student's scores in each aspect of science process skills in SMA Negeri 1 Kisaran City

\subsubsection{Student's Science Process Skills in SMA Negeri 2 Kisaran City}

Student's science process skills in SMA Negeri 2 Kisaran City as a whole was grouped in good category (table 1 and table 3). Looking from its each aspect of science process skills (figure 4), it was found out that the highest aspect obtained was aspect of observing (96.62, very good category) and the lowest aspect was hypothesizing (63.62, poor category).

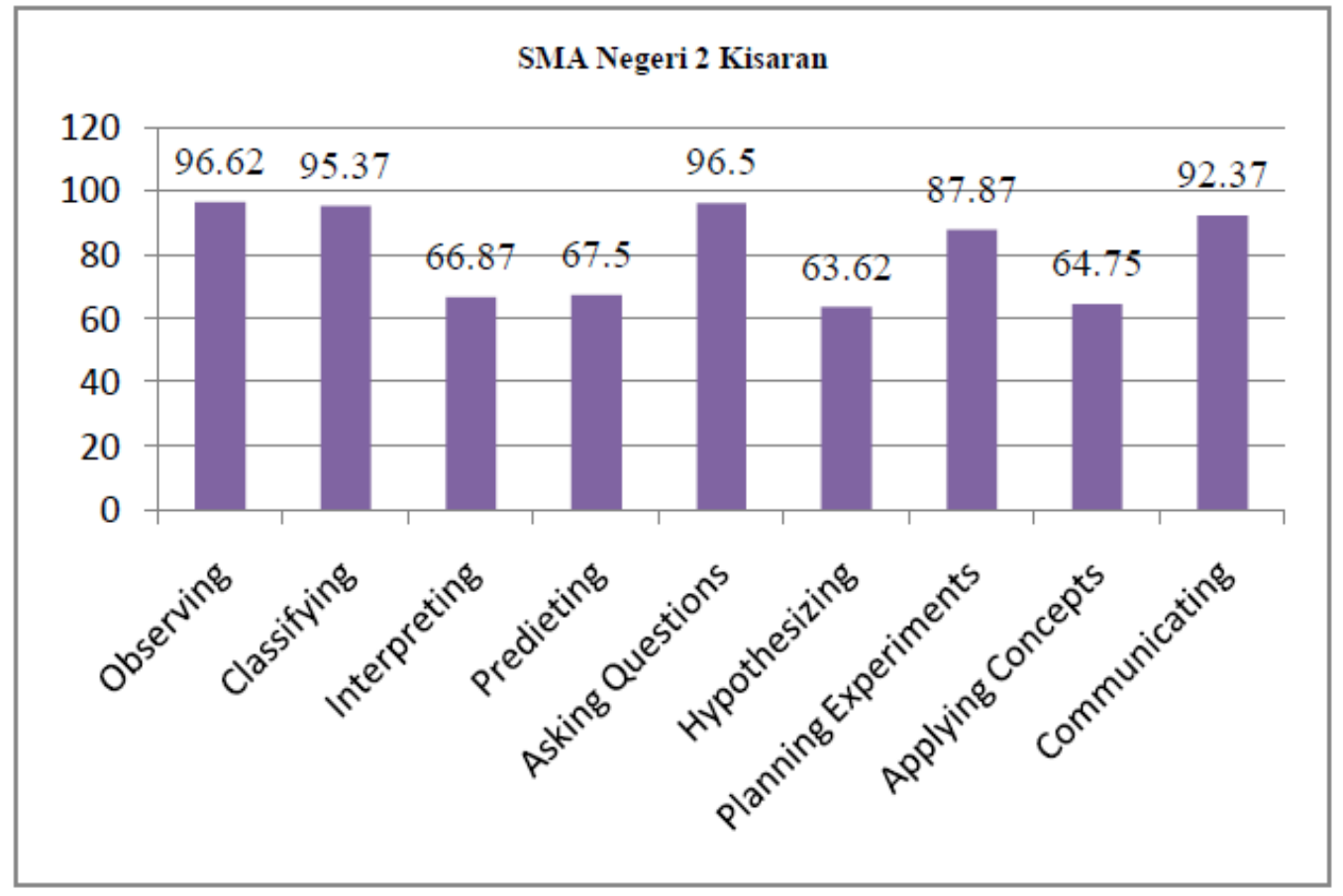

Figure4: Bar chart of student's scores in each aspect of science process skills in SMA Negeri 2 Kisaran City

\subsubsection{Student's Science Process Skills in SMA Negeri 3 Kisaran City}

Student's science process skills in SMA Negeri 3 Kisaran City as a whole was grouped in good category (table 1 and table 3). Looking from its each aspect of science process skills (figure 5), it was found out that the highest aspect obtained was aspect of asking questions (94.53, very good category) and the lowest aspect was hypothesizing (54.46, unsatisfactory). 
Inclusive Education: Education and Development of Persons with Disabilities in the Buea Municipality, Fako Division, South West Region of Cameroon

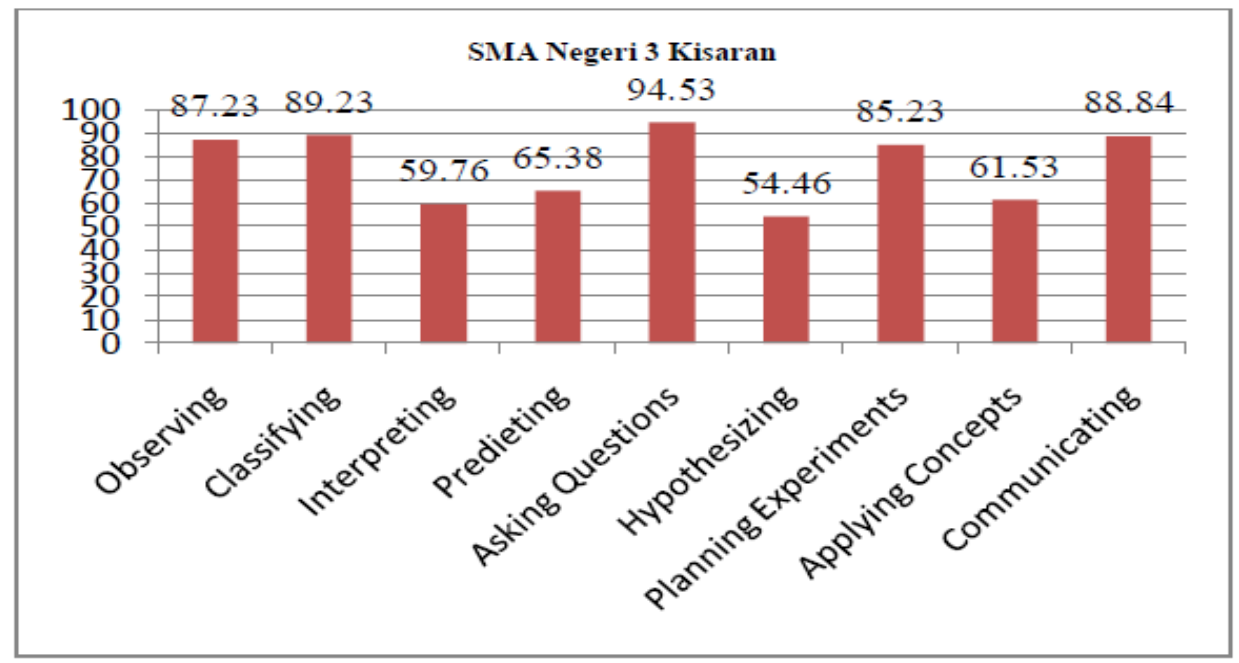

Figure5: Bar chart of student's scores in each aspect of science process skills in SMA Negeri 3 Kisaran City

\subsubsection{Student's Science Process Skills in SMA Negeri 4 Kisaran City}

Student's science process skills in SMA Negeri 4 Kisaran City as a whole was grouped in good category (table 1 and table 3). Looking from its each aspect of science process skills (figure 6), it was found out that the highest aspect obtained was aspect of asking questions (97.50, very good category) and the lowest aspect was hypothesizing (56.75, poor category).

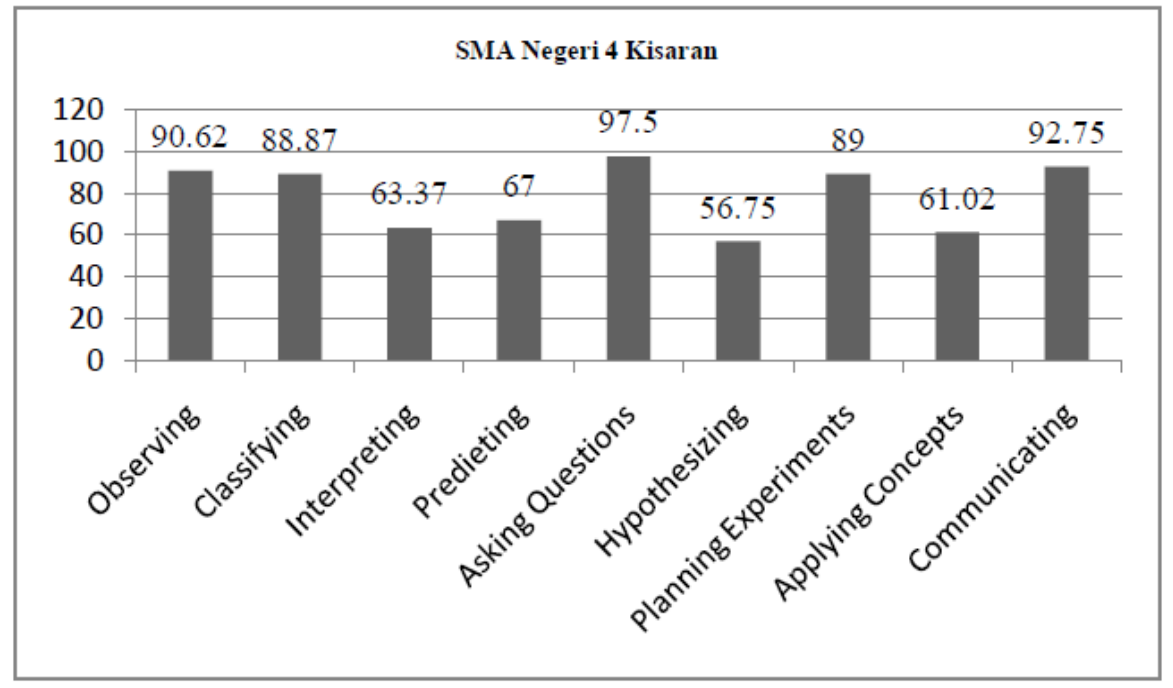

Figure6: Bar chart of student's scores in each aspect of science process skills in SMA Negeri 4 Kisaran City

\subsection{Discussion}

The reasons underlying the need to apply the process skills approach in daily teaching and learning activities are: (1) the development of science is accelerating so that it is no longer possible for teachers to teach all facts and concepts to students. To overcome this problem, students are given the provision of process skills that they can use to obtain knowledge without depending on the teacher.(2) Psychologists generally agree that children easily understand complex and abstract concepts when accompanied by concrete examples, reasonable examples according to the situation and conditions faced, and by practicing their own efforts to find concepts through treatment against physical reality, and through handling real objects. (3) The teacher's job is not to provide knowledge, but to prepare situations to lead children to ask questions, observe, experiment, and find facts and concepts themselves. (4) The discovery of science is not $100 \%$ absolute, the findings are relative. If we want to insert a scientific attitude in children, then children need to be trained to always ask questions, think critically, and seek possibilities for answers to a problem. In other words, children need to be fostered to think and act creatively. (5) Teaching and learning process must not be separated from the development of attitudes and values in students (Semiawan, 1996). 
Inclusive Education: Education and Development of Persons with Disabilities in the Buea Municipality, Fako Division, South West Region of Cameroon

The results of data analysis of science process skills in four schools showed that each school has the prominent aspect of science process skills. In line with Kurniawan's (2016), the level of science process skills of respondents were low, especially in terms of understanding concept of science process skills. Yuniarti's (2014) stated that science process skills student whom use scientific approach based worksheet was higher than the one who use conventional worksheet. Further, Roviati (2016) stated that by applying learning based science process skills, students learning activities in each meeting will be increase. Overall, this proved that learning based science process skills can improve student's activity in learning.

\section{CONCLUSION}

Result of this research showed that student's science process skills in Kisaran City in topic of environmental pollution were in good category. Students in SMA Negeri 2 Kisaran have the highest average score in science process skills, followed by SMA Negeri 4, SMA Negeri 1 and SMA Negeri 3 Kisaran. Based on its aspects, the highest score obtained was from aspect of observing (96.62), which was in very good category. The lowest score obtained from aspect of hypothesizing (54.56) which was in unsatisfactory category.

\section{REFERENCE}

[1] Afolaby, F., \& Akinbolala, A., O. 2010. Analysis of Science Process Skills in West African Senior Secondary School Certificate Physics Practical Examinations in Nigeria. Amrican-Eurasian. Journal of Science Reseacrch, 5 (4): 234-240.

[2] Akani, O. 2015. Levels of Possession of Science Process Skills by Final Year Students of Colleges of Education in South-Eastern States of Nigeria. (IISTE). Journal of Education and Practice. Vol.6, No.27.

[3] Arikunto, S. 2006. Dasar-dasar Evaluasi Pendidikan. Jakarta: Bumi Aksara

[4] Chebii, R. 2012. Effects of Science Process Skills Mastery Learning Approach on Students Acquisition of Selected Chemistry Practical Skills in School. Journal Sceintific Research. Vol.3, No.8, 1291-1296.

[5] Ergin, O., \& Aktamis, H. 2008. The Effect of science Process Skills Education on Students Scientific Creativity, Science Attitutde and Science Achievements. Asia-Pasific Learning Forum on Science Learning and Teaching, Vol. 9, Issue 1.

[6] Karamustafaoglu, S. 2011. Improving the Science Process Skills Ability of Science Student Teachers Using I Diagrams. Eurasian Journal of Physics and Chemistry Education (EJPCE),3(1):26-38.

[7] Kurniawan. 2016. Profil Pada Keterampilan Proses Sains. Bandung: Alfabeta.

[8] Pujiningrum, L. Setyo Admoko. 2017. Penerapan Model Pembelajaran Inquiri Terbimbing untuk Meningkatkan Keterampilan Proses Sains Materi Getaran Harmonik Di MAN Sidiarjo. Journal Inovasi Pendidikan Fisika (JIPF). Vol.06, No.03:203-208.

[9] Purwanto. 2013. Evaluasi Hasil Belajar. Yogyakarta: Pustaka Peajar.

[10] Semiawan, C. 1996. Pendekatan Keterampilan Proses. Jakarta: PT. Gramedia

[11] Subiantoro, A, W. 2011. Pentingnya Praktikum dalam Pembelajaran IPA. Yogyakarta: Universitas Negeri Yogyakarta.

[12] Rostika. 2012. Pengaruh Latar Belakang Sosial Ekonomi Keluarga dan Sikap Ilmiah pada Sains. Universitas Airlangga Program Studi: Pendidikan Biologi. Surabaya: Universitas Airlangga.

[13] Roviati, E. Yuliani, Dewi. 2016. Penerapan Pembelajaran IPA Berbasis Keterampilan Proses Sains Untuk Meningkatkan Literasi Sains Pada Mata Pelajaran IPA Dikelas VII Materi Pokok Pencemaran Lingkungan Di SMPN 1 Cikijing: Jurnal Science Education: Vol.5 No.2: 122-135.

[14] Rutten, N., Van Joolingen, W.R., \& Van Der Ven J. T. 2012. The Learning Efeects of Computer Simulations in Science education. Journal of Computers \& Education. 58:136.

\section{AUTHORS' BIOGRAPHY}

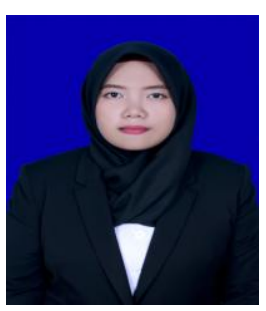

Leny Herawati, S.Pd, is a Biology Education Postgraduate student at Postgraduate Program of Universitas Negeri Medan (State University of Medan), Medan, North Sumatera, Post code 20221, Indonesia. She obtained her Sarjana Degree (S1) in Biology Education from Universitas Negeri Medan ((State University of Medan), her obtaining Master Programe in Biology Education on Universitas Negeri Medan (State University of Medan). 


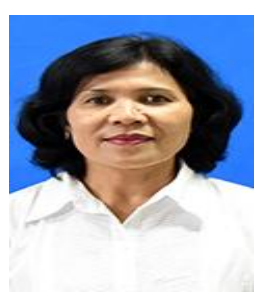

Dr. Melva Silitonga, M.Si, is a Lecturer at Graduate and Postgraduate Program of Universitas Negeri Medan (State University of Medan), Medan, North Sumatera, Post Code 20221, Indonesia. She obtained her Sarjana Degree (S1) in Biology Education from IKIP Medan, her Master Degree (S2) In Biology Program from Institut Pertanian Bogor and her Doctor (S3) Biology Program from Universitas Sumatera Utara (University of North Sumatera).

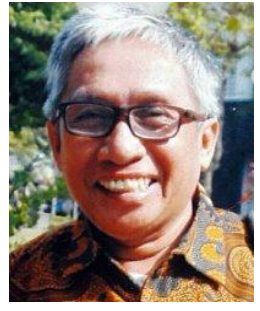

Prof.Dr. Ir. Ahmad Rafiqi Tantawi, M.Si, is a Lecturer at Graduate and Postgraduate Program of Universitas Negeri Medan (State University of Medan), Medan, North Sumatera, Post Code 20221, Indonesia. He obtained his Sarjana Degree (S1) Plant Protection from Universitas Sumatera Utara (University of North Sumatera), his master degree (S2) in Fitopatologi from Universitas Gajah Mada (University Gajah Mada) and his Doctor Degree (S3) Fitopatologi from Universitas Gajah Mada (University Gajah Mada).

Citation: Melva Silitonga, et.al. “Analysis of Student's Biology Science Process Skills in High Schools of Kisaran City". International Journal of Humanities Social Sciences and Education (IJHSSE), vol. 6, no.6, 2019, pp. 41-48. doi: http://dx.doi.org/ 10.20431/2349-0381.0606006.

Copyright: (C) 2019 Authors. This is an open-access article distributed under the terms of the Creative Commons Attribution License, which permits unrestricted use, distribution, and reproduction in any medium, provided the original author and source are credited. 